\title{
PALAVRA E UTOPIA: ANTÔNIO VIEIRA MISSIONÁRIO
}

\author{
Edimara Lisboa \\ Universidade de São Paulo
}

\begin{abstract}
Resumo: Neste artigo discutiremos a imagem de Antônio Vieira, o "imperador da língua portuguesa", no dizer de Fernando Pessoa, apresentada no filme Palavra e Utopia (2000), do cineasta português Manoel de Oliveira, em contraste com algumas biografias do jesuíta e analisando uma das escolhas dos excertos literários para compor a diegese do filme. Por privilegiar sua faceta missionária, a da defesa dos índios e dos negros escravizados no Brasil Colonial, o filme acaba por configurar um Vieira visionário e atual. Um Vieira muito a frente de seu tempo, detentor de um discurso humanístico avant la lettre, cujo desenvolvimento prático somente começaria a difundir-se após a Revolução Francesa e que no Brasil somente ganharia estatuto oficial após a assinatura da Lei Áurea, de 1988, tendo passados quase duzentos anos da morte de Vieira. Manoel de Oliveira encontra no contexto das comemorações dos 500 anos do "Descobrimento" do Brasil ocasião para revisitar esse personagem do nosso passado comum e repensar essa figura importante do universo lusófono.
\end{abstract}

Palavras-chave: Manoel de Oliveira. Literatura. Cinema.

"O discurso é apenas um tecido de agudezas, sucedam-se elas em cascata, ou se ordenem numa composição geométrica de conjunto"

Antonio J. Saraiva

\section{Introdução}

João Lúcio de Azevedo, o "mais idôneo dos seus biógrafos" (BOSI, 2011, p. 10), divide a vida e a obra do padre Antônio Vieira em seis períodos. "O religioso" (1608-1640) é o jesuíta em formação, muito dedicado aos estudos eclesiásticos, e cujas primeiras relações na esfera política se dá na conjuntura das invasões holandesas à Bahia. "O político" (1641-1650) é o homem de confiança do rei D. João IV, confessor da rainha e preceptor do príncipe herdeiro, que conquista a fama de grande orador, envolve-se na política e nas embaixadas em Holanda, França e Roma “O missionário” (1651-1661) está de volta ao Brasil, desconsolado 
com a política, envolve-se na evangelização dos índios e negros em S. Luís do Maranhão. "O vidente" (1661-1668), novamente em Portugal, está às voltas com a Inquisição por conta de suas profecias de teor messiânico-ufanista e vê-se forçado a partir para Roma em busca da absolvição papal. "O revoltado" (1669-1680) inquieta-se com o governo de D. Pedro, que o mantém afastado da política, é desprezado pela corte e criticado por vários setores da sociedade. "O vencido" (1681-1697) se estabelece definitivamente na Bahia, onde se dedica à redação e acomodação de sua obra, além de acercar-se das questões políticas locais.

No filme Palavra e Utopia (2000, Portugal-França-Espanha-Brasil, 132', 35MM, cor), Manoel de Oliveira também compartimenta a vida e a obra do escritor seiscentista, distinguindo o jovem, o maduro e o velho Antônio Vieira, interpretados inclusive por três atores diferentes. Ricardo Trêpa representa o sacerdote recém-ordenado e a vivacidade com que empresta a voz sagaz àqueles que não falam (a língua portuguesa): os índios e os negros. Luís Miguel Cintra anima o Vieira maduro, que conquista o mundo com a exuberância de seu discurso e engenhosidade de suas ideias, que consegue o apoio do rei D. João IV à sua empreitada contra a escravidão dos índios, porém é impedido de concretizar as reformas que pretendia para o Brasil. Cabe a Lima Duarte dar a ver os vários anos da velhice do jesuíta, a agonia das doenças e a decisão de retornar definitivamente à Bahia, retomando a defesa dos direitos dos índios e enfrentando os desmandos das autoridades em Salvador. ${ }^{1}$

Manoel de Oliveira não deixa de retratar os momentos mais significativos da biografia vieirista: a atenção dada à invasão holandesa na Bahia, o penoso processo inquisitorial em Coimbra, o sucesso em Roma, o cuidado com a publicação de seus sermões e de outros livros, a História do Futuro e a Clavis Prophetarum, quando de volta ao Brasil. Entretanto, a forte participação na política do Reino e as propostas para a viabilização de um império português, a que Lúcio de Azevedo está sempre atento, passam ao largo no filme de 2000. A todo tempo e a cada escolha dos excertos de sermões e cartas procura-se mostrar aquele Vieira que Azevedo chama de "o missionário".

\footnotetext{
${ }^{1}$ Essa divisão nos ficou mais clara depois de ouvir a entrevista que Lima Duarte concedeu à Versátil para acompanhar a versão brasileira do filme em dvd, distribuída desde 2009. Diz ele o seguinte: "[...] Primeiro, a opção do Manoel de Oliveira por três atores para interpretar o padre Antônio Vieira não foi [não se ateve apenas à questão cronológica: um ator para o jovem, um autor para o homem e um ator para o velho Antônio Vieira. Não foi isso. Ele pensou no estágio emocional e intelectual de cada padre Antônio Vieira. O jovem Antônio Vieira, interpretado pelo [pelo sobrinho [pelo neto do Manoel de Oliveira, ele [ele teve que interpretar principalmente a grande descoberta do jovem sacerdote: o outro. [...] Depois teve um outro que foi o Miguel Cintra, que é um ator exuberante, maravilhoso, foi falar dessa descoberta na Europa. E falou nas cortes da Suécia, em Roma, ele falou do outro. Este outro que ele descobriu aqui no Brasil. Este outro que está no índio, que está no negro, que está no colonizador e no colonizado. [...] E por fim, decepcionado por não ter [por não encontrar guarida pra o seu discurso. Por seu discurso não ter tido eco nas grandes cortes, e mesmo no vaticano, perseguido pela inquisição. Ele desanimado diz: eu vou voltar pra minha gente, pra o Brasil. E de Salvador pra cima, por $2.000 \mathrm{~km}$, chegou à Amazônia, claro, S. Luís do Maranhão, ele ergueu 16 igrejas e ensinou o catecismo em 7 línguas diferentes. Um gênio".
} 
Aliás, essa divisão feita por Azevedo da vida do jesuíta em períodos ou fases foi bastante criticada, por colocar em gavetas estanques as várias facetas de Antônio Vieira, responsáveis por seus diversos epítetos: pregador extraordinário, audacioso em seus sermões, apóstolo dos índios, vassalo zeloso de el-Rei, embaixador comprometido, político ardiloso, amigo de cristãos-novos, defensor da liberdade dos índios e negros, poeta humaníssimo, arauto do Quinto Império. Alcir Pécora chega a dizer que teria sido essa divisão de Azevedo a responsável por estabilizar "o engano do Vieira multifacetado e simultaneamente compartimentalizado", cuja vida foi marcada por "etapas bem definidas e aparentemente inconciliáveis" (1994, p. 60). Ainda assim, se a "mão" do biógrafo deixa ver um personagem Vieira "agudamente esquizofrênico", também permite entrever a convivência de suas muitas facetas e como elas vão se reconfigurando.

Se levarmos em conta que em seus filmes Manoel de Oliveira propõe sempre uma leitura crítica, muito sua, de outros textos (literários, históricos, multissemióticos), é possível dizer que a opção por privilegiar a faceta missionária, da catequese e da defesa dos índios e negros do Brasil, reflete o intuito de configurar uma personagem mais coesa e mais una, e por que não dizer mais ficcional. Palavra e Utopia é um filme que prima pela precisão histórica, mas que é declaradamente uma "planificação" dos dados biográficos de Vieira, que "seriam de menor interesse se os desligasse[mos] dos sermões e cartas". ${ }^{2}$ Oliveira propõe, com isso, um desafio aos estudiosos da relação cinema-literatura, sempre atentos a seus filmes, ${ }^{3}$ pois se são abundantes na história do cinema adaptações de romances, contos e peças de teatro, como pensar, em termos de análise fílmica, uma obra que dialoga com toda a biobibliografia de um

\footnotetext{
${ }^{2}$ Como consta na Nota de intenções de Oliveira:

"PALAVRA E UTOPIA é o título do projecto de um filme muito particular. O assunto versa sobre a vida do padre António Vieira, famoso pelos seus sermões. Podemos e devemos salientar, que ele próprio não considerou os seus sermões a cousa mais importante de sua vida. No entanto, os dados bibliográficos seriam de menor interesse se os desligasse dos sermões e cartas. Cartas e sermões, porém, são palavras. Foi sob esta óptica que procurei desenvolver uma planificação para o filmẹ: púlpitos do Brasil, em São Salvador da baía e em S. Luís do Maranhão, naturalmente em Lisboa, Coimbra e, também, em Roma; encontros em Portugal com Inquisidores, com o Rei e com o Príncipe Regente; no Brasil com governadores e colonos; em Roma com o Papa e a Rainha Cristina da Suécia; na Holanda com um Rabi; em França, quando de regresso a Portugal, embarcado descia rio Garona, em direção a Bordeaux, cegou duma vista; e ainda as tantas vezes que atravessou o Atlântico, tendo até naufragado perto dos Açores quando, expulso do Maranhão, veio pela última vez a Portugal.

Contar esta estória, amarrado à vigilância por mim solicitada ao historiador O. João Marques, tanto vale como uma amarra a pés e mãos, como força para uma abordagem aos sermões guiados pelas anotações preciosas das cartas do próprio Vieira.

Assim me debrucei sobre esta forma de narrativa fiel a tempo e lugares, e original por não recorrer desta vez a reconstituições de época, como é hábito comum quanto a filmes históricos. Enfim, uma construção sui generis muito do meu agrado por tudo se condensar num estilo reduzido ao essencial.

Assim, PALAVRA E UTOPIA não será nem um filme documentário, nem histórico, nem didáctico, nem biográfico, embora siga uma ordem cronológica. Será, sim, uma ficção com todas as premissas que esta possa permitir. Sem perder a correcção histórica, poderá ter o seu lado didáctico, na medida em que a ficção se afirma pela autenticidade dos documentos que a guiaram sem se afastar mas do que o rigor permitia.
}

Manoel de Oliveira, agosto de 1999" ${ }^{3}$ Basta lembrar o artigo de Michelle Sales intitulado "Manoel de Oliveira: um cineasta-escritor", em que não apenas a presença de obras literárias é analisada ao longo de toda a sua filmografia como também se defende a ideia do cinema oliveiriano como um "cinema literário", em que a Palavra assume o epicentro e é fonte das principais temáticas e opções estéticas (SALES, 2007). 
autor canônico de vasta produção, já que os recortes de textos literários presentes em Palavra e Utopia não apenas precisam ser localizados como compreendidos em seu suporte e contexto de origem.

Neste trabalho pretendemos discutir a construção do personagem Vieira de Palavra e Utopia, em contraste com algumas das principais biografias do autor e pondo em questão opções de recorte dos excertos literários. O historiador P. João Francisco Marques, professor da Universidade do Porto, um dos mais conhecidos estudiosos portugueses dos sermonários seiscentistas e assessor histórico deste filme, nos dá uma possível chave de leitura quando diz que "do enorme acervo documental que nos legou publicado retira-se muito de autobiográfico e muito do que há de mais incisivo e significativo na obra de Vieira. O filme Palavra e Utopia foi buscar o seu perfil autobiográfico aos sermões, às cartas e aos outros escritos". ${ }^{4}$ Uma cinebiografia que não estaria, portanto, interessada em revelar o indivíduo que se esconde por detrás do autor literário, e sim em salientar os indícios autobiográficos espalhados pela obra de Vieira, sem prescindir de tratar as temáticas e dar a ver a força de expressão que o imortalizaram como escritor engenhoso, "imperador da língua portuguesa". 5 De todo modo, Oliveira preocupa-se em delimitar uma personagem coesa e coerente, amarrando o melhor possível os excertos que elegeu. Apesar dos três atores escolhidos para interpretá-lo, o Antônio Vieira de Palavra e Utopia consegue escapar à armadilha de

\begin{abstract}
retornar ao lugar comum do Vieira 'contraditório', o mais resistente lugar comum da fortuna crítica do jesuíta, um anacronismo longamente compartilhado por positivistas, românticos e marxistas, católicos ou não, que postula incoerência quando Vieira fala ao mesmo tempo e com as mesmas finalidades do Deus católico apostólico romano, do milenarista Quinto Império do mundo e da política de fortalecimento da monarquia portuguesa. [...] Manoel de Oliveira produz uma personagem que sustenta uma unidade consistente de ação e propósito. (PÉCORA, 2003, p. 130).
\end{abstract}

\title{
A dimensão histórica: utopia vieirista
}

Uma das grandes fascinações da arte cinematográfica é ter como matéria-prima fragmentos diretamente retirados da realidade. Sendo arte a habilidade de compartilhar com outrem uma imaginação própria a respeito da vida, através da representação de um fragmento de mundo, o cinema é das formas artísticas a mais colada ao real. Um pintor representa uma cena, que viu ou vislumbrou, fixando na tela branca um conjunto de traços e cores capazes de

\footnotetext{
${ }^{4}$ Em depoimento concedido a António Costa - para compor os Extras do dvd do filme distribuído em Portugal pela Lusomundo.

Célebre epíteto de Vieira engendrado por Fernando Pessoa em Mensagem, no segundo poema da parte "Os avisos". De Vieira é dito que em vida teve a fama e agora tem a glória.
} 
sugerir uma cena idêntica. Um escultor modela a partir do barro ou outro material argiloso uma superfície que sentiu ou presumiu, criando uma figura com as dimensões perceptuais similares. Um músico expressa uma ideia ou sentimento, inspira uma série de imagens ou de ruídos do mundo, através da organização e reconstrução melódica de um conjunto de notas musicais. Um escritor reproduz um acontecimento, presenciado no cotidiano ou no sonho, através de palavras, a fim de inocular na mente do leitor um acontecimento análogo. Um teatrólogo coordena um conjunto de outros trabalhos artísticos (de atuação, de decoração, de música etc.), apresentados simultaneamente num local específico (o palco), de modo a expor sua imaginação própria a respeito da vida de forma mais direta e mais similar a ela. A pintura, a escultura, a música, a literatura, o teatro estão, assim, ligados à criação. É preciso refazer “com as próprias mãos" para fixar e transmitir qualquer coisa.

A particularidade do cinema, enquanto arte, está na não necessidade de criar, já que o processo mecânico de captação pela câmera de cenas, de sons e de fatos da vida e da arte permite a fixação e transmissão direta do que se deseja dar a ver. Claro que "a mão humana" continua presente, no momento da filmagem (escolha do ponto de vista) assim como no processo de montagem (concatenação do que foi filmado), mas lida com um material expressivo tão idêntico ao mundo que se confunde com ele. É ao recortar o real que a câmera dá a impressão de realidade, e através de seus movimentos, "reforça a impressão que há um mundo do lado de lá, que existe independentemente da câmera em continuidade ao espaço da imagem percebida" (XAVIER, 2005, p. 22). Assim, o retângulo da imagem é visto como uma janela (ou espelho) que relaciona o mundo dito real com o mundo da representação artística (projetado na tela de cinema) "como um duplo do mundo real" (p. 25).

Por ser um recorte do que existe ou existiu, ${ }^{6}$ o cinema tem uma dimensão histórica, de registro do passado ou sobre o passado, pois preserva a cópia (esse duplo) de um determinado lugar num determinado tempo. Há nele um valor referencial, devido "[a]o poder que o cinema tem de fixar as coisas, de modo que nos permite vê-las mais tarde", como diz Manoel de Oliveira em entrevista (BAECQUE; PARSI, 1999, p. 30), ainda que seu valor introspectivo ("da mão do artista") seja inegável, inclusive nos filmes documentais que buscam o objetivismo e a imparcialidade.

\footnotetext{
${ }^{6}$ Penso aqui não apenas nos filmes pretensamente realistas, já que por mais plástico e subjetivo que seja, todo cinema trabalha com "material concreto", com imagens e sons que foram colhidos/construídos em algum espaço/tempo independente da câmera. Mesmo o material proveniente de computação gráfica existe para além do aparato técnico propriamente cinematográfico, tendo existência em outros suportes técnicos.
} 
Por isso Palavra e Utopia, apesar de declaradamente ficcional, encanta por oferecer ao espectador "a vida e a obra de António Vieira", ${ }^{7}$ um dos mais importantes eruditos da literatura e da história comum de Portugal e do Brasil. E é sobre este ponto que iremos refletir primeiramente. O filme "enquanto documento histórico e como discurso sobre a história" (MONTEIRO, 2004, p. 7) atraí pela possível abordagem didática, que daria a conhecer não apenas uma figura importante, mas fatos significativos de todo o século XVII, tendo em vista a longevidade do jesuíta, que nasceu em 1608 e só veio a falecer em 1697.

\begin{abstract}
Vieira foi, sem contestação, uma das maiores figuras do século XVII; e o foi não apenas como escritor e como pregador que dominava, com invulgar talento, a arte de escrever e de falar; mas também como inteligência, capaz de compreender os grandes problemas religiosos, morais, políticos, sociais e econômicos de sua época, e como homem de ação. Daí não ser possível entender e avaliar a cultura brasileira de seu tempo, sem conhecimento de sua vida e de sua obra (quinhentas cartas e duzentos sermões). (AMORA apud VIEIRA, 1975, p. 10).
\end{abstract}

Ainda assim, "Quem conhece Antônio Vieira?” é a pergunta de abertura com que Clóvis Bulcão justifica sua biografia romanceada, publicada em 2008 por ocasião do quarto centenário de Vieira, apostando que a maioria dos brasileiros não o conhece. Recorda que os currículos de história do Brasil para ensino normal abordam dos seiscentos apenas a produção açucareira e o início da colonização e que há um maior espaço dado para dois outros importantes jesuítas, Manuel de Nóbrega e José de Anchieta. A fim de melhor explicar os fatos da vida de seu biografado, Bulcão acaba dedicando um grande número de páginas à memória do contexto histórico em que esses fatos estavam inseridos. E, desse modo, a figura vieirista termina servindo apenas de gancho para lições de história, num texto de leitura ligeira que em nenhum momento exige conhecimentos prévios ou pausas para pesquisa para ser integralmente compreendido.

A estrutura desse livro o aproxima bastante do gênero filme de época, ${ }^{8}$ sempre preocupado em oferecer ao espectador os pormenores dos fatos históricos relevantes ao entendimento do enredo, impedindo que o desconhecimento da história comprometa a

\footnotetext{
${ }^{7}$ Como se lê no frame final do trailer do filme, cuja pré-estreia foi em 31 de agosto de 2000, na Itália, e a estreia oficial em 17 de novembro em Portugal. No Brasil, foi exibido pela primeira vez apenas cinco anos depois, em 21 de outubro de 2005, abrindo faustamente a Mostra Internacional de São Paulo daquele ano. A crítica da Folha.com diz o seguinte a cerca da dificuldade do filme: "Apesar de o filme seduzir pela extrema beleza fotográfica, o ritmo lento e a aparente desconexão entre os fatos estão sendo considerados de difícil compreensão para o público brasileiro [...] Abusando do estilo verborrágico, por meio de longos diálogos de um português intricado e pouco compreensivel para o brasileiro, o filme peca no descaso com a comunicação com o público, que fica um tanto perdido na contextualização dos fatos históricos e impaciente com os discursos intermináveis e distantes da realidade contemporânea", em http://www1.folha.uol.com.br/folha/ilustrada/ult90u5387.shtml.

${ }^{8}$ Vale lembrar as ligações de Bulcão com o cinema e a televisão. O seu primeiro romance histórico, $A$ quarta parte do mundo, inspirou a série de documentários Brasil-a quarta parte do mundo, trabalhou no programa Um pé quê? da TV Futura e escreveu em 2006 o livro infanto-juvenil Leopoldina - a princesa do Brasil que reconfigura a personalidade histórica satirizada por Carca Camurati no filme Carlota Joaquina: princesa do Brazil (1996).
} 
compreensão da história contada em película. É justamente em oposição a esse tipo de texto fílmico que Manoel de Oliveira concebeu Palavra e Utopia (vide a nota de intenções reproduzida integralmente na nota 2). Ao representar o contexto em que os sermões vieiristas foram pregados e suas cartas enviadas - os dois gêneros que lhe garantiram o distinto espaço no cânone literário -, o filme certamente nos transporta para o passado, preenche nossos olhos e ouvidos com situações, personagens e lugares característicos do século XVII. Entretanto, e justamente por focar nos sermões e cartas, Oliveira abre mão de narrar o entorno da época, exigindo que o espectador complete as lacunas que vão aparecendo pelo caminho.

Após um longo plano-sequência em que nos convida a caminhar por uma exuberante floresta tropical ao som de uma canção tipicamente lusitana, ${ }^{9}$ suscitando aqueles tempos do século XVII em que as terras brasileiras estavam sob administração portuguesa, o filme inicia no ano de 1663, ponto crítico da história do impressionante orador, quando ele é convocado pelo Tribunal do Santo Ofício para se defender das acusações de heresia. Oliveira põe o grande teorizador e defensor da ideia do Quinto Império a se apresentar a nós ele próprio, resumindo sua origem pessoal e familiar, enquanto observamos seu momento mais crítico.

Em seguida, e em princípio em flashback, a história passa a ser contada cronologicamente. Fugindo da tradicional estrutura da biografia, que segue a concordância cronológica dos acontecimentos no intuito de manter a precisão histórica, o centenário cineasta se vale de um clássico recurso literário, o principiar in media res, ${ }^{10}$ para dizer-nos que o filme se trata, antes de tudo, de uma obra de ficção e não de uma reconstituição de época pretensamente fidedigna. Seu discurso é baseado em documentos históricos sim, e procurará ser o mais fiel possível a eles, mas foi elaborado segundo a imaginação, a memória e a reflexão de um autor que não se quer apagar. Mesmo que o restante do filme siga a ordem cronológica, o tom ficcional já ficou demarcado, e será mantido, através de muitos outros recursos discursivos, ao longo de todo o filme, segundo o muito oliveiriano modo de contar histórias em película.

a busca incessante pela experimentação formal, o desligamento entre a arte e a vida social, e a separação nítida entre o autor e o fruidor das obras. Muito das escolhas e opções estéticas de Oliveira advêm daí: do desejo de afirmar-se enquanto autor e gênio criador, da vontade incansável de sacudir o público com uma linguagem formalista, artificiosa e anti-natural que proíbe qualquer tentativa de identificação e sonho. (SALES, 2010, p. 96).

\footnotetext{
9 A composição é de Carlos Paredes, "o homem dos mil dedos", mestre da guitarra portuguesa e um dos grandes símbolos da cultura lusitana.

${ }^{10}$ Não cronologicamente, mas partindo de uma cena significativa, a fim de conquistar o leitor, e recuar ao passado, na forma de cena presente, conforme surjam obscurecimentos que necessitem de explicação.
} 
A infância e pré-adolescência de Vieira são excluídas, inclusive fatos significativos como a chegada ao Brasil e o episódio do estalo. ${ }^{11}$ Dois planos simbólicos de danças circulares sagradas, uma indígena outra africana, antecipam os indicativos do ethos do protagonista: dos tempos do noviciado de Vieira não vemos no filme o prestígio que alcançou com sua personalidade arrebatadora e sucesso acadêmico, mas apenas os "outros estímulos" que ajudaram a compor seu entendimento da atuação religiosa:

\begin{abstract}
Adolescente ainda, foi Vieira levado para a aldeia do Espírito Santo, a sete léguas de Salvador, uma das povoações de índios sob a catequese e a jurisdição da Companhia. Em vez das influências da família, recebia todos os estímulos da obra apaixonante, que continuava a acção prestigiosa de apostolados heróicos e virtudes sublimes, que o milagre mais de uma vez sagrara: moldar almas pelos princípios duma civilização superior; dirigi-las para Deus pelos caminhos duma religião que temperava a severidade da moral com a fascinação do culto; defendê-las, com frequência, contra a cupidez dos colonos, sentindo, sob a roupeta, o poder inerme mas temido, vitorioso ainda que odiado. Compreende-se como, bem mais do que as sabatinas escolásticas, tudo isso o devia tentar, porque propiciava a irradiação, pelo domínio e pela luta, de uma personalidade que se adivinha de irreprimível exuberância, talhada para mais alguma coisa do que as competições dialécticas no claustro - a acção, directiva e dominadora. (CIDADE, 1979, p. 18).
\end{abstract}

A personalidade do jovem Vieira, interpretado por Trêpa, nada tem de "irreprimível exuberância". ${ }^{12}$ É com um coleguismo pueril que ele pede ao "confrade noviço" que lhe ensine "a fala dos índios", depois de explicar que o seu desejo de entendê-los está relacionado à necessidade de impedir o avanço da escravidão no Brasil. Na sequência, a cena dos primeiros votos reforça a imagem do Vieira atento ao problema da escravidão, já que ouvimos o voto secreto: "Comprometo-me também dedicar a minha vida ao serviço dos negros e dos índios" (2000, 5'28'). Cabe ao espectador atentar para o desenrolar dos fatos e verificar se e como esse juramento será cumprido. ${ }^{13}$ 11 Conta-nos Ernest Carel que na chegada à Bahia "o jovem Antônio, então com oito anos, caiu com uma
enfermidade que o levou as portas da morte. Os pais desolados mantinham-se à cabeceira do pequeno
moribundo, mas o padre Fernando Cardim, aproximando-se do leito, disse-lhes convictamente "que não morreria
o menino; porque Deus o guardaria para cousas grandes, para crédito da nação portuguesa e para honra da
Companhia de Jesus"” (CAREL, s.d., p. 7) e se essas palavras proféticas não convencem o leitor da missão
divina de Vieira, na página seguinte o biógrafo arremata com um fato que André de Barros, primeiro biógrafo de
Vieira, diz ter ouvido dele próprio, e que aqui chamei episódio do estalo: "o piedoso colegial mostra-se assíduo e
cheio de ardor nos seus estudos, mas nos primeiros tempos, apesar dos esforços para superar seus condiscípulos,
a lentidão da memória parecia paralisar-lhe a inteligencia e cobri-la com um véu. Como tinha uma grande
devoção pela Virgem, num dia em que ajoelhado diante da sua imagem lhe desvendava as tristezas do seu
coração e lhe suplicava auxílio, produziu-se-lhe subitamente na cabeça uma espécie de dilatação, acompanhada
de violentíssimas dores, e desde então possuiu uma memória admirável, passando a ter em seus condiscípulos,
não mais rivais mas sim admiradores" (idem, p. 8).
12 Não apenas Hernani Cidade, mas também Lúcio de Azevedo ("os vôos de seu gênio, desvairados as vezes") e
Ernest Carel ("religiosa audácia") atribuem a Vieira uma personalidade extravagante.
13 "Não era, porém, prático se perdessem no esforço silencioso das missões talentos que muito bem podiam
contribuir para o prestígio intelectual da Companhia no Mundo" (CIDADE, 1979, p. 23). Tão logo foi ordenado,
Vieira afastou-se das missões e passou a lecionar Teologia, Retórica e Filosofia, mais um dado que a economia
do filme não deixa entrever. Já Ernest Carel faz questão de lembrar que "no meio de tão agradáveis ocupações, o
tempo do magistério passou depressa; ao fim de três anos os superiores pensaram em dedicá-lo aos estudos de
teologia e filosofia, e foi grande o seu espanto quando o brilhante professor de eloquência lhe pediu que o

Anuário de Literatura, ISSNe: 2175-7917, vol. 17, n. 1, p. 136-155, 2012 
Treze planos à frente, e imediatamente após o take da dança africana, mostra-se Vieira pregando pela primeira vez. Não seu primeiro sermão, pregado na Quaresma de 1633, mas um excerto do "Sermão XXVII do Rosário" que torna emblemática sua crítica dura à escravidão no Brasil, não apenas a dos índios, mas inclusive a dos negros:

Entra uma nau de Angola e desova no mesmo dia quinhentos, seiscentos e talvez mil escravos. Estes atravessam o mar Oceano [...] para viver e morrer cativos. O que geram os pais e o que criam a seus peitos as mães é o que se vende e o que se compra. Oh trato desumano, em que a mercadoria são homens! (2000, 10'07'’10'39',).

A escolha deste sermão garante a emolduração de um Vieira delator do regime escravista, seja por oprimir os nativos seja por subjugar os trabalhadores trazidos da África. ${ }^{14}$

A passagem do ministério do jovem para o do Vieira maduro, vivido por Cintra, é bastante truncada. Depois do intertítulo que indica essa mudança, mostra-se ainda Ricardo Trêpa recebendo a notícia da restauração de Portugal, em 1640, para no plano seguinte ouvirmos Miguel Cintra recitar um trecho do "Sermão dos Bons Anos", pregado em 1642. Esse talvez o momento em que mais nitidamente se vê que a escolha por três atores para interpretar o padre Vieira não diz respeito apenas à cronologia. ${ }^{15}$ Depois de ir à Europa e conquistar a admiração de D. João IV, o Vieira maduro retoma em S. Luís do Maranhão seu trabalho missionário. Sutilmente percebemos, no filme, o prestígio que Vieira ganha junto ao novo rei graças à sua lábia, ${ }^{16}$ mas o glorioso trabalho como diplomata e os sucessivos

dispensassem de tais estudos, pois desejava consagrar-se ùnicamente à instrução dos negros e dos índios, confessando então o voto secreto que havia feito no fim do seu noviciado, de dedicar toda a sua vida à conversão dêstes infelizes. Aprendera mesmo o quimbundo, língua que se fala em Angola, e desejava de todo coração entregar-se à catequização dos índios" (CAREL, s.d., p. 12).

"Os "Sermões do Rosário" foram pregados na Irmandade dos Pretos de um engenho a partir de 1633, porém uma boa parte deles foram pregados apenas após o regresso do autor ao Brasil em 1681. Publicados pela primeira vez em 1688 sob o título Maria Rosa Mystica, não foram informados por Vieira o local e a data da pregação de cada sermão. Em Paiva (1999) encontramos informações acerca da pregação de alguns desses sermões, mas não sabemos precisar se o sermão XXVII foi pregado na década de 1630 , como indica o filme, ou apenas na década de 1680. Antônio Soares Amora, por sua vez, afirma que "não há dúvida de que esta série [que Vieira menciona em uma passagem do sermão] é formada pelos sermôes XIV, XX e este, que é o XXVII, da série maior, intitulada Maria, Rosa Mística, e foi dirigida à Irmandade dos Negros do Rosário (de Salvador), em 1633" (VIEIRA, 1975, p. 87). E para explicar uma passagem em que Vieira comenta os sessenta anos do domínio espanhol, indicativo de que o sermão teria sido pregado após 1640, Amora acrescenta: "não há dúvida de que este sermão foi dito em Salvador, em uma irmandade de negros devotos da Senhora do Rosário; não há dúvida de que foi o terceiro e último proferido pelo pregador, em 1633, sobre a liberdade dos negros; no entanto, Vieira refere-se aos sessenta anos do domínio espanhol em Portugal (1580-1640), como fato já passado. Como explicar a contradição? E simples: quando, nos anos 70, Vieira começou a reescrever seus sermões, para edição em obra completa, cometeu enganos cronológicos, como o desta passagem. Enganos explicáveis e também justificáveis" (idem).

Ainda que se possa pensar ter sido um lapso da montagem mostrar Trêpa ouvindo a notícia da restauração de Portugal, em 1640, depois do intertítulo de passagem do jovem para o Vieira maduro, é inegável que a distância temporal entre o último sermão proferido por Ricardo Trêpa - o "Sermão pelo Bom Sucesso das Armas de Portugal contra as de Holanda", pregado na Igreja de Nossa Senhora da Ajuda, na Bahia, em 1640 - e o primeiro sermão pronunciado por Luís Miguel Cintra - o "Sermão dos Bons Anos", pregado na Capela Real, em Lisboa, em 1642 - é realmente curta.

16 "Captando desde o primeiro instante a simpatia de D. João IV, Antônio Vieira instala-se ao mesmo passo na corte. Não como os fidalgos e criados que por obrigação do cargo habitavam com o rei, mas visitante assíduo, estimado pela conversação viva, atendido pela lúcida compreensão dos negócios do Estado. [...] Vieira pela sugestão pessoal, própria dos oradores de lei, pela verbosidade que entorpecia e quase lançava em hipnose o 
fracassos políticos que o obrigaram a retornar ao Brasil são deixados de lado. Diferentemente, a montagem sugere que Vieira aproveitou a restauração para interceder junto ao rei em favor dos índios, pois coloca lado a lado o "Sermão dos Bons Anos", o primeiro pregado em Portugal, e a carta à D. João IV datada de 6 de abril de 1654, em que o autor avisa que novamente irá a Lisboa para negociar novas leis de apoio aos índios.

Não sem antes por em cena o belíssimo "Sermão de Santa Teresa", destacando dele um trecho em que Vieira lembra a causa indígena, ${ }^{17}$ mostra-se D. João IV concedendo ao jesuíta um documento que deixa "os direitos dos índios e justiça melhor acaudelados como é vosso desejo e conveniente" (2000, 19'40’'). Mas nem mesmo o apoio do rei conseguiu alterar o estado das coisas no Maranhão, o clero secular e o poder civil não cooperavam. A nomeação de André Vidal Negreiros não trouxe nenhuma melhora à situação dos índios, que continuavam sendo arrastados das missões para as lavouras dos colonos. No filme não vemos o nosso padre lutando ou se manifestando junto aos governantes nem as suas diversas cartas de denuncias escritas neste período, mas sermões que demonstram poeticamente como ele levava ao púlpito as preocupações das "gentilidades do Maranhão" (18'14'). Expulso do Brasil após ficar detido e cercado no Colégio dos Jesuítas, como o foram muitos padres após a morte de D. João IV, em fins de 1656, a situação de Vieira piorou quando o príncipe D. Afonso comunicou à rainha, até então no trono, que iria assumir o poder. "O novo governo anulou a defesa dos padres jesuítas e retirou seus privilégios no Maranhão. Os demais membros da Companhia até poderiam retornar à colônia, exceto o seu Geral, o próprio Vieira" (BULCÃO, 2008, p. 145).

Sem o apoio régio, num momento de extrema vulnerabilidade, Vieira foi detido pela Inquisição. Conforme André de Barros, os motivos do processo eram os "textos das Sagradas Escrituras, que interpretara, diverso estado da Igreja em tempos futuros que prometia; livros que tinha escrito, ou tivera pensamento de escrever, foi a matéria amplíssima, de que the formaram crime afetos differentes" (BARROS, 1746, p. 270). Sua situação se agravou quando a carta "Esperanças de Portugal, Quinto Império do Mundo", em que defende a ideia de que

lento D. João IV. Lábia chamava ele ao poder sugestivo dessa palavra que o rendia" (AZEVEDO, 2008, t.I, p. 75-76).

Este é um sermão panegírico dos mais eloquentes pregados por Vieira, quando ele tendo escapado de um terrível naufrágio, acaba "acaso e bem acaso" aportando na ilha de São Miguel e pregando no colégio da Companhia de Jesus. As analogias entre a vida de S. Teresa e a parábola das dez virgens acabam por levá-lo ao episódio do naufrágio de Jonas, rapidamente comparado ao seu: "Testemunhas são os anjos do Céu, cujo auxílio invoquei naquela hora, e não o de todos, senão daqueles somente que têm à sua conta as almas da gentilidade do Maranhão. Anjos da guarda das almas do Maranhão, lembrai-vos que vai este navio buscar o remédio e salvação delas" (2000, 18'10"-18'29'). E, como era-lhe próprio, aproveita para aproximar os textos bíblicos dos episódios concretos e contemporâneos, questionando quais foram as suas ações, e as ações dos demais jesuítas que o ouviam, em favor dos índios e negros: "Dir-me-eis, que ainda que não tendes agora as boas obras, que tendes propósitos de as fazer depois. E se antes desse depois vier o Esposo. [...] Se antes desse depois vier a morte? Se antes desse depois vos pedirem conta? Atreveis-vos a estar no inferno para sempre?" (VIEIRA, 1993, p. $847-8$, v.3). 
D. João IV iria ressuscitar para realizar as previsões de Bandarra, foi localizado pelo tribunal. Em Palavra e Utopia, é neste ponto que o flashback encerra-se e voltamos ao presente da narrativa. Vinte minutos são dedicados ao inquérito de Vieira (2000, 26'24'’-46'15'). Sem chances de defesa, ele é aconselhado a partir para Roma, onde conquista as graças de religiosos importantes, bem como do próprio papa e da rainha Cristina da Suécia, "cujo extraordinário e sublime génio se satisfaz mal ainda do que não é ordinário" (48'55'). Anos depois, isso lhe garante, por parte do príncipe D. Pedro, a incumbência de ações diplomáticas por toda a Europa.

Durante os seis anos em que viveu em Roma, Vieira não se desligou do quadro político e econômico de Portugal e do mundo, e nessas viagens continuou a negociar acordos que favorecessem a visibilidade internacional do reino. $\mathrm{O}$ momento de passagem do maduro para o velho Antônio Vieira, representado por Duarte, se dá quando em viagem pelo rio Garona, em direção ao porto de Bordeaux, começam as suas enfermidades, motivo pelo qual retornará definitivamente à Bahia. Mas se a reclusão na Quinta do Tanque se deu pela fragilidade de sua saúde, isso não lhe impediu de continuar sua primeira e principal missão, seu grande desejo, que para a época parecia mesmo uma utopia, a defesa dos índios e dos negros.

O filme traz um longo trecho do "Sermão do Espírito Santo", pregado no Colégio dos Jesuítas, quando partiam para o rio Amazonas um grande número de religiosos, nele Vieira salienta a necessidade de se aprender as várias línguas do mundo para catequisar respeitando o outro. Mostram-se ainda suas conferências junto às autoridades religiosas e políticas locais, sua proposta para um justo e viável pagamento pelos trabalhos realizados pelos índios.

Cada vez mais enfermo, Vieira não deixou de escrever cartas indicando seu estado de saúde e o do Brasil. Quando lhe era impossível escrever, ditava-as para que o padre José Soares ${ }^{18}$ as redigisse. Até a última carta recolhida por J. Lúcio de Azevedo, ${ }^{19}$ endereçada a Sebastião de Matos e Sousa a 10 de julho de 1697, pouco antes da morte de Vieira, vê-se sua preocupação com o Reino: "Das cousas públicas não digo a V.M. ${ }^{\text {cê }}$ mais que ser o Brasil hoje um retrato e espelho de Portugal [...] de cá escrevem-se mentiras e de lá responde-se com

\footnotetext{
${ }^{18}$ O padre José era seu "companheiro imutável" (AZEVEDO, 2008, t.II, p. 319), quem o incitava à compilação completa de todos os seus sermões e escritos morais.

19 João Lúcio de Azevedo também divide os volumes das cartas de Vieira segundo as diferentes fases. Num primeiro bloco temos as primeiras cartas escritas por ele, entre 1626 e 1646, numeradas de I a XLIX. Depois aparecem as cartas da Primeira Jornada a Roma, entre fevereiro e junho de 1650 . Na sequência os Tempos de Missionário, entre junho de 1651 e 1662, e que encerra o primeiro volume. O segundo volume reúne as cartas dos tempos do Desterro e processo em Coimbra e a Segunda Jornada a Roma. Já o terceiro volume traz outras cartas do Desterro e processo em Coimbra, dos Seis anos em Portugal e dos Anos finais na Bahia, além de outras onze cartas inéditas.
} 
lisonjas, e neste voluntário engano está fundada toda a nossa conservação" (VIEIRA, 1970, p. 713-4). Vieira é por fim impedido de manifestar publicamente suas ideias antiescravistas, élhe negado o direito de votar e ser votado. Do processo que abriu para revogação dessa ordem, mostra-se no filme o resultado atrasado. É o próprio Manoel de Oliveira que traz ao quarto do Vieira já morto o parecer de Roma em que o Padre Geral anula a privação e lhe devolve o direto à voz passiva e ativa.

O filme de Manoel de Oliveira acaba, desse modo, por apresentar as ideias de Vieira, salientando a beleza e a força de expressão de suas irresistíveis palavras, de forma indiscutivelmente lógica e tranquilamente aceitável à luz dos valores e princípios contemporâneos. Mais do que isso, delega a Vieira a posição de figura visionária, muito à frente de seu tempo, como se suas propostas de libertação dos índios e desaprovação da escravidão dos negros ${ }^{20}$ não fizessem parte do pensamento do grupo social a que fazia parte, a Companhia de Jesus. Ao devolver a palavra à Vieira apenas após a sua morte, Oliveira parece reforçar a imagem de um Vieira precursor do pensamento humanitário que começou a se desenvolver durante a Revolução Francesa. Um Vieira anacrônico, formulador de uma utopia que só poderia ser compreendida no futuro, no atual presente.

\section{A vocação literária: palavra vieirista}

Frequentemente, a crítica e o público salientam a dificuldade do cinema de Manoel de Oliveira, que a cada filme "desafia o espectador, complicando-lhe a esperança de um sossego sistematizante, classificador" (TEIXEIRA, 2004, p. 69). Palavra e Utopia é certamente dos seus filmes mais difíceis, pois além de ser entrecortado, fragmentado, descontínuo, com a maioria das cenas constituindo blocos narrativos independentes e não integrados em sequências maiores, é um filme que não remete a um texto-fonte, mas a toda biobibliografia de Antônio Vieira, já que o que se filma dela acaba por evocar (ou provocarnos a respeito de) todo o resto. Embora não seja uma adaptação, as relações que este filme estabelece com a literatura vieirista remetem para a inesgotável vocação literária do cinema.

A literatura e o cinema, enquanto obras de arte, possuem entre si uma relação muito mais forte do que a que mantêm com as demais artes, pois ambas se matizam no contar

\footnotetext{
${ }^{20}$ No filme perde-se totalmente de vista que Vieira censurava o fato - a escravidão dos negros - mas não proibia a ação - de os escravizar. Muitas vezes Vieira se posicionou contra qualquer tipo de mercantilização de homens, trabalho forçado e não remunerado, mas como a prioridade da Companhia era garantir a liberdade dos índios, cuja catequese era sua razão de existir, muitas vezes ele aponta a escravidão dos negros como cruel, mas necessária.
} 
histórias. Bello (2004) explica que é a fabula e sua configuração como estrutura de profundidade, que possibilita a transposição do texto de uma arte para outra, e que

\begin{abstract}
Muito mais do que a tantas vezes evocada (e sem dúvida pertinente) capacidade imagética da literatura, é esta dimensão [fabular] a principal responsável pelo fato de a adaptação da literatura ao cinema ser um fenômeno incomparável com qualquer outro tipo de relação entre a literatura e outras artes (obviamente aproveitado ao máximo pela poderosa máquina de fabricar histórias e de fazer dinheiro que é a indústria cinematográfica). (BELLO, 2004, p. 4).
\end{abstract}

Porque ambas organizam temporalmente "um conjunto de acontecimentos ligados entre si que nos são comunicados ao longo da obra" (TOMACHEVSKI apud CEIA, online) ${ }^{21}$, ao contar histórias, o cinema acaba empregando técnicas a muito conhecidas da literatura, bem como a literatura tem tomado emprestado uma série de recursos narrativos próprios do cinema. "Não é de estranhar, assim, que o cinema, como arte narrativa que é, receba um precioso legado discursivo da literatura (e vice-versa, se pensarmos nos autores da Lost Generation, nos autores surrealistas ou nos escritores afectos ao nouveau roman)" (SOUSA, 2008 , p. 212). Houve, talvez por isso, um movimento que alguns críticos desenvolveram nas décadas 1940 a 60 em torno do cinema avant la lettre (pré-cinema) em que se vasculhava os clássicos buscando neles o que poderia haver de cinematográfico (SOUSA, 2008). Certamente não podemos dizer que as obras encontradas por eles transpuseram os recursos do cinema, como o faz muitas vezes a literatura contemporânea, mas servem de exemplo para demonstrar a inclinação narrativa que aproxima ambas as artes e explica a fecundidade das transposições, tanto de livros para filmes como o contrário.

Técnicas que atribuímos ao cinema, como o close up e a visão panorâmica, já serviam há muito à literatura, seja em prosa ou em verso, não porque esses autores tiveram uma intuição visionária, mas porque tanto o cinema como a literatura contam histórias através de imagens em movimento, ou melhor, de situações. Sejam elas mais cultistas, para aproveitar os termos barrocos, ou mais conceptistas. Em outras palavras, tanto o cinema como a literatura expressam figuras (imagens do mundo) e/ou ideias (imagens da mente) conforme as necessidades da história que desejam contar.

O "Sermão de S. Gonçalo", pregado na Bahia não se sabe ao certo quando ou em que igreja, ${ }^{22}$ um dos sermões mais longos que escreveu, é o texto escolhido para compor a última

\footnotetext{
${ }_{21}^{21}$ No verbete sobre Fabula do e-Dicionário de Termos Literários Carlos Ceia.

${ }^{22}$ Muito provavelmente tenha sido pregado a 10 de Janeiro, no dia do santo, na igreja do Retiro, na do Rio Vermelho ou na de São Francisco do Conde, no Recôncavo Bahiano, entre os anos de 1682 e 1687, talvez ainda em 1688, ano anterior à publicação do sermão, ou talvez nunca tenha sido pregado (FREIRE, página da web; site da Paróquia de S. Gonçalo).
} 
cena no filme em que Vieira sobe ao púlpito. Uma espécie de biografia de S. Gonçalo de Amarante, o sermão é transposto aos picados nessa belíssima cena em que se convida o espectador a repensar o filme todo, para dentro e fora da fábula.

Voltando ao texto integral do sermão percebemos que os procedimentos utilizados por Vieira para traçar a vida e as obras milagrosas de S. Gonçalo têm algumas paridades com os procedimentos da construção da figura de Vieira neste filme. "Onde há muito o que eleger, não pode haver muito o que duvidar" (VIEIRA, 1993, v.2, p. 1223) são as palavras iniciais do sermão em que Vieira justifica seu recorte e expõe a dificuldade que encontrou "para eleger as maiores" grandezas do santo a fim de "pregar dele as mais admiráveis". Explica que acabou por encontrar a resposta na Bíblia, em Lucas 12:38, "E, se vier na segunda vigília, e se vier na terceira vigília, e os achar assim, bem-aventurados são os tais servos".

Em Palavra e Utopia, esta cena começa com um plano médio em que a câmera se posiciona à altura e distância dos fiéis, um pouco adiantada ao ponto de não mostrar os demais ouvintes, podendo apenas lhes escutar os ruídos, que se encerram tão logo Lima Duarte se aproxima do púlpito. Num corte, a câmera é posicionada atrás do púlpito e no escuro e estreito daquele espaço restrito ao pregador capta, em contra-plongeé, um quadro dentro do enquadramento, onde se dispõe ao centro um Vieira que ao explicar a passagem do Evangelho de Lucas, se põe igualmente em vigia.

\footnotetext{
No tempo de Cristo, os soldados dividiam a noite em quatro vigias. E porque a nossa vida, como diz Job, é milícia, e neste mundo vivemos às escuras, ou com pouca luz como de noite; divide o Senhor a mesma vida do homem em quatro partes com o nome de quatro vigias. Na primeira idade, que é a dos meninos, ainda os não tenta o mundo; na última, que é a de velhos, já os não tenta o mundo. (2000, 37’0037'31').
}

Novo corte, e a câmera retorna à posição do plano inicial da cena, agora num contraplongeé leve, direcionado ao alto do púlpito. A banda sonora, entretanto, não sofre ruptura. "A virtude sem batalha, que nos meninos é inocência, e nos velhos é desengano, quanto mais se está em paz, e fora da guerra, menos se tem de vitória, de sólida, e forte virtude" (37'32'”37'50'). Todo trecho transcrito é um excerto, um pouco alterado e com saltos, da segunda parte do sermão, em que se explica porque Lucas, na passagem bíblica, salienta apenas a segunda e a terceira vigia da vida dos homens como aquelas em que eles devem se mostrar preparados para a volta de Cristo.

Entendido assim (pois assim se deve entender) o Evangelho, parece que ele por si mesmo nos tem já dividido o discurso em duas partes, e que segundo elas devemos 
tratar das duas principais idades do nosso santo: a segunda, que nos mancebos é florente, e a terceira, que nos varões é madura; sendo uma e outra na sua perfeição, ambas foram cheias de flores, e ambas de frutos. Mas posto que assim pareça a outros, a mim, cuja é a eleição, não me parece. Não são as excelências de S. Gonçalo tão pouco grandes, que caibam em tão estreitos limites. (VIEIRA, 1993, v.2, p. 1226).

Vieira esclarece desse modo porque optou por tratar não de duas, mas das quatro, ou melhor, das cinco vigias de S. Gonçalo. Na terceira parte trata da primeira vigia: "foi santo, e admirável santo S. Gonçalo na primeira idade de menino, porque não foi menino menino, senão menino homem" (p. 1226). E comprova sua tese com o episódio do batizado do beato, quando ele, ainda bebê, não chorou ou aceitou o peito da ama, mas estendeu muito crentemente os braços para a imagem de Cristo. Para reforçar a grandiosidade desse fato, como de costume, Vieira faz analogias a episódios bíblicos. Compara-o com Adão que nascido homem agiu como menino e com o apóstolo Paulo na passagem, da I Epístola aos Corinthios XIII:11, em que diz: "Quando eu era menino, falava como menino, sentia como menino, discorria como menino, mas como me fiz homem, o que era de menino, aniquilei" (BIBLIA, 1848[n.t.], p. 190).

Assim como não coloca no filme a primeira idade de Vieira, Manoel de Oliveira elimina dessa cena a terceira parte do sermão de S. Gonçalo. Após uma pausa, Lima Duarte continua:

\footnotetext{
Mancebo era Abel, e que pastor mais religioso? Mancebo era Jacob, e que pastor mais virtuoso? Mancebo era David, e que pastor mais animoso e corajoso? A idade da velhice é já muito fria para ações tão alentadas, e ardentes. Senhores... O pior gado de guardar, é o homem. A maior falta que se experimenta nos pastores de hoje, é a do valor. Ah quantos milagres vemos por aí, e quantos homens, e alvitres milagrosos, mas todos à custa do pão alheio, e nenhum do seu? Quer Cristo que os seus pastores saibam atar, e desatar, e não sejam homens que não atam nem desatam! (38'00-39'31')'.
}

Retirado de diversas passagens da quarta parte, esse excerto salienta a posição de jovem pastor que, como o Vieira de Trêpa, saiba guardar o seu rebanho e fazê-lo crescer sem explorá-lo, conquistar a fama com seus próprios esforços, textos e ideias. A mensagem principal da quarta parte vai no mesmo sentido. Foi na idade de mancebo que S. Gonçalo, diz Vieira, foi "pastor de almas (ofício tão perigoso para a própria, como útil para as alheias) de tal sorte acudiu a uma obrigação sem faltar a outra, que a ambas satisfez adequadamente" (p. 1232). Dentre os milagres feitos por ele nessa altura, dá-se destaque à transformação dos pães brancos em carvão e de novo em pães brancos. Vieira salienta que, depois de feito o milagre, S. Gonçalo fez o pão retornar ao seu estado original e, além disso, não o confiscou à Igreja, 
"para perpétua memória, e horror do caso", mas o devolveu ao dono original. E como sempre procura fazer em seus sermões, transforma o fato em exemplo para os dias atuais: não devemos procurar fazer milagres (ou fortuna) à custa do pão alheio, devemos também tanto saber fazer como saber desfazer o que foi mal feito. Aproveita, ainda, os pães como metáfora:

\footnotetext{
Esse milagre teve avesso, e direito: e tais hão-de ser os homens, que governam homens. O bom pastor não há-de ser todo bondade [...]. Há-de ter excomunhão para os rebeldes, e absolvições para os arrependidos: e tanto para os brancos como os pães, como para os pretos como os carvões. Há-de saber fazer e desfazer, converter e desconverter. (p. 1236).
}

Da quinta parte, sobre a terceira vigia, a idade de varão, também não há excerto equivalente nesta cena. Assim como da idade madura de Vieira deu-se no filme mais atenção à causa dos negros e dos índios, que para os historiadores aqui mencionados não era a ocupação principal de Vieira neste período, mas os sonhos do Quinto Império e a causa dos cristãos-novos. Todavia, a idade de varão traçada aqui para S. Gonçalo é similar à configuração do Vieira maduro: "porque tanto que entrou nela, saiu da pátria, e partiu peregrino [...], como viveu, [...] todo restante da mesma idade" (p. 1238) e "não foi só lícita, e louvável, mas verdadeiramente santa; porque ele a empreendeu não só por espírito, e devoção particular sua, senão por impulso, e vocação especial de Deus" (p. 1240). Vieira justifica o abandonar as ovelhas, para partir em peregrinação, através do conceito de chamado divino. "Quanto à quarta vigia, foi santo, e admirável santo São Gonçalo de Amarante porque passando-se a um deserto a fazer vida eremítica, soube deixar o mundo, antes que o este o deixasse. Fez o que deveriam fazer todos os velhos, e não sabemos de nenhum que o faça" (39'38'-40'03'). Tocando pela primeira vez no nome do beato que é o assunto desse sermão, a cena cresce em dramaticidade. Finalmente chegamos à idade da velhice, sexta parte do sermão, em que se explica que "não tendo S. Gonçalo porque fugir de si, fugiu de nós para o seu deserto" (p. 1247) com o intuito de passar seus últimos dias em contemplação. Nesse ponto há um zoom da câmera, grifando o trecho seguinte:

\footnotetext{
Só a morte que traz consigo, ou após si, a velhice, como disse Séneca, é a morte sem esperança. Mata a doença, mata o incêndio, mata o naufrágio, mata a espada, mata a seta, a descoberta, ou atraiçoada. Mas de todos estes gêneros de morte, muitos homens escaparam. Só da morte pela velhice, dessa nunca ninguém escapou. (40'04'’- 41'04').
}

Lima Duarte, olhando direto para o olho da câmera, fala da condição de seu personagem, igualmente velho, e deixa entrever, na forma como pronuncia essa passagem, a 
alusão que se faz a um fragmento vieirista anteriormente utilizado por Manoel de Oliveira no filme Non, ou a vã glória de mandar (1990, Portugal-França-Espanha, 110', 35MM, cor). A velhice, como o non, mata a esperança, "que é o último remédio que deixou a natureza a todos os males" (1990, 1h36'16').

O que o filme não aponta é que S. Gonçalo, como Vieira, tentando se afastar do mundo na sua idade da velhice - um indo para o deserto e o outro se resguardando na Quinta do Tanque -, não deixou de atuar, "mas toda dentro e toda fora de si, juntamente está obrando no exterior, e no interior contemplando" (p. 1249). Enquanto Vieira continuou com suas pregações, ensinos, envio de cartas e projetos para reformas na política local, S. Gonçalo construiu a ponte de Amarante e "a deixou perfeita, e acabada para tanto bem de tantos, antes que a última idade lhe acabasse a vida" (p. 1254).

A sétima parte trata da quinta vigia, "que eu prometi do nosso santo, não já de vivo e mortal, senão de imortal, e depois da morte" (p. 1254). Salienta-se os milagres pós-túmulo por meio dos quais Vieira testifica a santidade de S. Gonçalo, comparando-o a Cristo. "Assim obra como imortal, depois de morto, o grande imitador de Deus homem” (p. 1258).

A continuação do sermão, no filme, é retirada da sétima e última parte, em que Vieira tendo "acabado, ou deixado sem acabar" o seu discurso não deixa de lembrar que "os sermões de S. Gonçalo todos eram encaminhados à doutrina dos ouvintes, e não é lícito faltar à imitação do santo no seu próprio dia" (p. 1262). Se toma a construção de pontes como primeira lição, acaba por escolher como grande exemplo o seguinte: que procuremos acabar como S. Gonçalo começou, como menino homem.

\begin{abstract}
São Gonçalo, sendo menino, foi homem. E nós, sendo homens na idade, no mundo, na vida e em outros costumes, somos meninos. Ah, melhor o disse Séneca do que se pode traduzir na nossa língua. [Sim, é lástima haver de... haver de afrontar com a tradução de qualquer língua, a elegância destas palavras $]^{23}$ : Adhuc non solum pueritia in nobis, sed quod est gravius, puerilitas remanet: et hoc quidem pejus est, quod authoritatem habemus senum, vitia puerorum, nec puerorum tantum, sed infantium. ${ }^{24}$ (2000, 41'08',- 42'06'').
\end{abstract}

Esse último plano da cena concentra-se no trecho de nó do sermão, com uma pitada de ironia fina, muito ao gosto oliveiriano. Seria esse suntuoso filme, um de seus mais ambiciosos projetos, talvez "o mais grandioso" (BESSA-LUÍS, 2007, p. 43), simples troça de uma persistente meninice? Ou o ensinamento do sermão de S. Gonçalo que se quer dar a ver é o que o filme não mostra: a construção de pontes? Pontes que são símbolo do encontro dos

\footnotetext{
${ }^{23}$ A frase entre colchetes não é de Vieira, inserção de Manoel de Oliveira.

${ }^{24}$ Em português: Temos a autoridade de velhos e os vícios de meninos; e o pior é, que não só se vê em nós a meninice, que é defeito da idade, senão as meninices que o são do juízo.
} 
homens, dos seus desejos e das suas culturas, que permitem não apenas vislumbrar, mas efetivamente conhecer o lado de lá?

\section{Considerações finais}

O retrato de Vieira que Palavra e Utopia parece traçar é o de um personagem genial e incompreendido, "vítima das manobras de poder" (FERREIRA, 2007, p. 2) por seu caráter muito humano e fragilizado em contraste com a desumana e exploradora sociedade de seu tempo. Mesmo velho, e já sem vigor para lutar por melhorias para esta mesma sociedade vil, para difundir seu projeto utópico, ele pregará vários sermões e comprometer-se-á mais uma vez com a causa indígena tão logo retorna ao Brasil. Assim o filme o mostra e salienta. O que ganha destaque, da personalidade histórica Antônio Vieira, é a dimensão supostamente humanizadora e progressista de suas ideias.

Da longa história e diversificados projetos, o projeto da liberdade dos povos, o projeto humanístico de Vieira ainda é muito atual. Ao enquadrar este e não qualquer dos outros projetos, que aparecem complementarmente no filme, Manoel de Oliveira nos apresenta um ensaio sobre a história e não uma simples narração da mesma. "Na sua leitura de António Vieira, o cineasta evidencia o jogo de sutilezas e provocações com o sabor da linguagem seiscentista" (AVELLA, 2010, p. 70), que permite o amalgama sincrético "de real e simbólico, frustação e esperança, passado e futuro, dor e desejo, como forma específica do temperamento de uma nação" (p. 70). Convida o espectador não apenas a refletir sobre o seu biografado, mas a repensar o nosso estar no mundo. Foi com a insistência de homens como o padre Antônio Vieira que conseguimos avanços quando ao direito das pessoas e dos povos. Resta-nos questionar quais são os nossos projetos para garantir a concretização futura de ao menos uma utopia presente.

\section{Referências}

ANAIS DO XII SEMINÁRIO DE PESQUISA DO PROGRAMA DE PÓS-GRADUAÇÃO EM ESTUDOS LITERÁRIOS E VII SEMANA DE ESTUDOS TEATRAIS DA UNESP: Teatro, Cinema e Literatura: Confluências, Faculdade de Ciências e Letras da UNESP. Araraquara: UNESP, 2011. Disponível em: http://www.fclar.unesp.br/Home/PosGraduacao/StrictoSensu/EstudosLiterarios/anais_2011.pdf

AVELLA, Aniello Angelo. O 'Imperador' na grande tela. Dor, Desejo, Saudade e Utopia em António Vieira, segundo Manoel de Oliveira. In: BRIDI, Marlise Vaz; SIMAS, Monica; POMA, Paola (orgs.). Dor e Desejo. São Paulo: Paulistana, 2010. 
AZEVEDO, João Lúcio de. História de Antônio Vieira. Tomos I e II. São Paulo: Alameda, 2008 .

BAECQUE, Antoine de; PARSI, Jacques. Conversas com Manoel de Oliveira. Porto: Campo das Letras, 1999.

BARROS, André de. Vida do apostolico padre Antonyo Vieira. Lisboa: Nova Officina Sylviana, 1746.

BELLO, Maria do Rosário Lupi. Da imagem literária à imagem cinematográfica: o 'concreto' e o 'icônico' como vocação narrativa. In: V Congresso da APLC - Associação Portuguesa de Literatura Comparada. Lisboa: Universidade Aberta, 2004.

BESSA-LUÍS, Agustina. Vieira versus Campanella. In: BESSA-LUÍS, Agustina; OLIVEIRA, Manoel de. Um concerto em tom de conversa. Org. e intr. de Aniello Ângelo Avella. Belo Horizonte: Editora UFMG, 2007.

BIBLIA SAGRADA, contendo o velho e o novo testamento. Trad. P. Joao Ferreira A. d'Almeida. Nova York: Sociedade Americana da Bíblia, 1848.

BOSI, Alfredo. Antônio Vieira: vida e obra - um esboço. In: VIEIRA, Antônio. Essencial Padre Antônio Vieira. Organização e introdução de Alfredo Bosi. São Paulo: Penguin Classics Companhia das Letras, 2011.

BULCÃO, Clóvis. Padre Antônio Vieira. Um esboço bibliográfico. Rio de Janeiro: José Olympio, 2008.

CAREL, Ernest. Vida do padre Antônio Vieira. Trad. Augusto Souza. São Paulo: Editora Assunção Limitada, s.d. (Coleção Perfis Literários, 2).

CIDADE, Hernâni. P. ${ }^{e}$ António Vieira. A obra e o homem. 2. ed. Lisboa: Arcádia, 1979.

E-DICIONÁRIO DE TERMOS LITERÁRIOS CARLOS CEIA, disponível em: http://www.edtl.com.pt/

FERREIRA, Carolin Overhoff. A dimensão imaginária da palavra - o Quinto Império em Palavra e Utopia de Manoel de Oliveira. In: Anais do XI Encontro Regional da Associação Brasileira de Literatura Comparada. Literatura, Artes, Saberes / Sandra Nitrini, et al. São Paulo: Abralic, 2007. Cd-rom.

FREIRE, António Abreu. As Pontes (pelos 320 anos do Sermão de São Gonçalo). Disponível em: $\quad$ http://antonioabreufreire.bloguepessoal.com/118690/As-Pontes-pelos-320-anos-doSermao-de-Sao-Goncalo/

MONTEIRO, Miguel (org.). Cinema \& História. 6 a 10 de outubro de 2003. Lisboa: Centro de História da Universidade de Lisboa, 2004.

PAIVA, José Pedro (coord.). Padre António Vieira, 1608-1697: bibliografia. Lisboa: Biblioteca Nacional, 1999.

PÉCORA, Alcir. Teatro do Sacramento. A unidade teológica-retórica-política dos sermões de Antonio Vieira. São Paulo: Edusp; Campinas: EdUnicamp, 1994.

Manoel de Oliveira, dir. Palavra e Utopia. In: Luso-Brazilian Review, vol. 40, n. 1, summer 2003. Special Issue: António Vieira and the Luso-Brasilian Baroque. Guest Editors: Thomas Cohen and Stuart B. Schwarts. Madison: University of Wisconsin-Madison, 2003.

SALES, Michelle. Em busca do novo cinema português. Covilhão: LabCom Books, 2010. 
. Manoel de Oliveira: um cineasta-escritor. In: Anais do XI Encontro Regional da Associação Brasileira de Literatura Comparada. Literatura, Artes, Saberes / Sandra Nitrini, et al. São Paulo: Abralic, 2007. Cd-rom.

SARAIVA, Antonio J. $O$ discurso engenhoso. Estudos sobre Vieira e outros autores barrocos. Trad. Tereza de Araújo Penna. São Paulo: Perspectiva, 1980.

SITE DA PARÓQUIA DE S. GONÇALO: http://www.portal.ecclesia.pt/paroquia/pub/10/noticia.asp? jornalid $=10 \&$ noticiaid $=5838$

SOUSA, Sérgio Guimarães de. Breve apontamento sobre o cinema avant la lettre. In: OLIVEIRA, Anabela, et al. Diálogos lusófonos: literatura e cinema. Literatura, cinema e multiculturalismo no mundo lusófono 2006-2007. Coleção Cultura 1. Centro de Estudos em Letras, Universidade de Trás-os-Montes e Alto Douro e Cátedra Lindley Cintra, Universidade Paris Ouest-Nanterre La Défense. Vila Real: MMVIII, 2008.

TEIXEIRA, Rui de Azevedo. "Non, ou a Vã Glória de Mandar": um filme de vocação ensaística. In: MONTEIRO, Miguel (org.). Cinema \& História. 6 a 10 de outubro de 2003. Lisboa: Centro de História da Universidade de Lisboa, 2004.

VIEIRA, António. Sermões. Prefaciados e revistos pelo Ver. Padre Gonçalo Alves. 5 v. Porto: Lello \& Irmão Editores, 1993. [Obras completas do padre António Vieira]

Cartas. Coordenadas e anotadas por J. Lúcio de Azevedo. 3 v. Lisboa: Imprensa Nacional-Casa da Moeda, 1970.

Sermões. Problemas sociais e políticos no Brasil. Seleção, apresentação, introduções e notas de Antônio Soares Amora. São Paulo: Cultrix, 1975.

XAVIER, Ismail. O discurso cinematográfico: a opacidade e a transparência. 3. ed. revista e ampliada. São Paulo: Paz e Terra, 2005.

[Recebido em março de 2012 e aceito para publicação em junho de 2012]

\section{Work and Utopia: Antônio Vieira missionary}

Abstract: This article will discuss the image of Antônio Vieira, the "Emperor of the Portuguese language", in the words of Fernando Pessoa, featured in the movie Word and Utopia (2000), by Portuguese filmmaker Manoel de Oliveira, in contrast to some of the Jesuit biographies and analyzing one of the choices of literary excerpts that compose the film's diegesis. Because it favors their missionary side, of the defense of Indians and blacks slaves in colonial Brazil, the film turns out to set up a visionary and actual Vieira. A Vieira far ahead of his time, holding a humanistic discourse avant la lettre, whose practical development only begin to spread after the French Revolution and in Brazil only gain official status after signing the Lei Áurea, of 1988, after almost two hundred years of the death of Vieira. Manoel de Oliveira finds in the context of the celebrations of 500 years of "discovery" of Brazil occasion to revisit this character of our common past and rethink this important figure of the Lusophone universe.

Keywords: Manoel de Oliveira. Literature. Cinema. 